\title{
Communication Concientization of Inclusion Education in Palu
}

\author{
Ni Nyoman Suhermi ${ }^{1}$, Muh. Nur Ali ${ }^{2}$, Achmad Herman ${ }^{3}$ \\ 1,2,3 Universitas Tadulako, Palu, Indonesia \\ Komangalexander@gmail.com
}

\begin{abstract}
The aim of this is to uncover and analyze the responses of relevant stakeholders regarding the implementation of inclusive education in Palu City; participatory communication models regarding the implementation of inclusive education in Palu City through a concentrated perspective; and exploring the embodiment of a participatory communication model in the implementation of inclusive education in Palu City which involves related stakeholders. This study uses naturalistic research methods because of the research is carried out in natural setting. Data collection technique was carried out through observation, interviews, documentation, and FGD. The data analysis technique includes four stages, namely: data collection, data reduction, data presentation, and drawing conclusions or data verification. The results of this study indicate that: (1) The stakeholders involved in participatory communication provided suggestions regarding efforts which related to the implementation of inclusive education in Palu City; (2) The model of conscientization communication for the implementation of inclusive education in Palu City must involve various stakeholders consisting of local governments, schools, parents, NGOs, and local mass media; (3) The realization of the participatory communication model regarding the implementation of inclusive education in Palu City based on the involvement and participation of stakeholders which refers to their real participation in educational activities. Limitations and suggestions for further research are revealed in this study.
\end{abstract}

Keywords

conscientization; inclusive

education; naturalistic, cormunication participation

\section{Introduction}

Communication has become one of the focus of attention nowadays. Many experts argue that, communication is important and continues to develop. Communication in the development of the world of education has high complexity, namely how to convey and receive information is not easy, and becomes a challenge in the communication process. In the communication of the development of the world of education, the flow of information is a complex process, because it involves all existing stakeholders. Information does not only flow from the top down, but also from the bottom up and also flows among other stakeholders.

In relation to the development of the world of education, currently one of the centers of government attention is education for children with special needs. The children with special needs are children who experience physical, mental, emotional and social obstacles, so they need special educational services, which tailored to their deviations or disabilities. The education service model for children with special needs, which currently being widely implemented, is the inclusion model. Inclusive education is an educational service that requires Children with Special Needs to attend regular school education. The implementation of inclusive education really requires good management with involvement: 
school management, government, family, community, and related stakeholders play an important role in the development of inclusive education in various existing schools. Without the involvement of these stakeholders, the implementation of inclusive education in schools cannot be carried out well either.

Therefore, to form good cooperation between these stakeholders, a good relationship and communication are needed. The implementation of inclusion, which has not yet received a serious response from all levels of society, requires socialization of the clarity of its importance through good communication. Inclusive education, although it is an educational innovation for children with disabilities, they have the same right to live properly through education that facilitates their life, so that education, which has been a necessity, can be realized by all nations (Firdaus, 2010). The relationship between the importance of communication in practice and the development of inclusive education is very urgent, especially participatory communication, which so far has not been properly appreciated in the field.

Therefore, participatory communication refers to two-way communication based on dialogue between people, groups and organizations that empowers various stakeholders to share and exchange information, knowledge and experiences fairly. Participatory communication in its use is flexible. Van de Fliert (2010) states that participatory communication is not a specific pattern of communication.

Inclusive education development efforts must be based on the belief in people's capacity to see what is best to do when they seek freedom of expression, and how to actively participate in the task of transforming and developing that education. This is the main concept of a participatory communication model which concentrated in relation to the development of inclusive education in existing schools (Servaes, 1996).

According to the concept of participation, structural change involves a redistribution of power. In the field of mass communication, many communication experts agree that structural changes must first be made to form participatory communication policies. Therefore, through the participatory communication model, it is expected to be able to form cooperation between related stakeholders in order to realize the implementation of good inclusive education in schools. Community participation consisting of parents, family members, community leaders, entrepreneurs, and stakeholders has been regulated in Law number 20 of 2003 concerning the national education system Article 7 paragraph 1 states that: "Parents have the right to participate in choosing educational units and obtain information about the development of their children's education. " Article 8 states: "the public has the right to participate in the planning, implementation, monitoring and evaluation of educational programs." Meanwhile, Article 9 states: the community is obliged to provide resource support in the provision of education. "Meanwhile, the participation of social organizations has also been regulated in Law number 8 of 1985 concerning community organizations. Chapter I article 1 reads: ... "What is meant by Community Organization is an organization voluntarily formed by members of the public who are citizens of the Republic of Indonesia on the basis of the same activities, profession, function, religion, and belief in God Almighty, to play a role. as well as in development in order to achieve national goals ...".

Based on this description, it needs a participatory communication concientization model in the framework of cooperation at various levels involving stakeholders for the realization of the implementation of Inclusive Education in schools in Palu. 


\section{Review of Literature}

\subsection{Library Study and Theoretical Framework of Concientization Education}

Concientization education comes from Freire's thinking. Freire proposes an important term in Pedagogy of The Oppressed with his theory of awareness (conscientizacao) or what is often referred to as "Conzcientization". Concientization is an understanding of the real situation that is being experienced by students. Although the last area that he wants to aim at is systemic change, Freire's education aims at liberation and humanization by seeing that "awareness" (concientization) is the core of his education. Education should aim to make students aware of the social reality of Willian Smith A. in (Syaikhudin, 201).

This shows how critical thinkers respond to expected changes in preparing the nation's generation through education. Freire's philosophy as written by, (Rohina et al., 2019) which begins from real life about life in a world where most humans suffer in such a way while others enjoy the labors of others in unfair ways even groups enjoying this precisely the minority of mankind. In terms of numbers alone, it shows that circumstances transform history and become subjects through one critical reflection.

Based on this explanation, it can be concluded that awareness education is a form of education in various aspects of human life which is closely related to obtaining the right to education including awareness that needs to be disseminated to all parties so that awareness touches all dimensions of human life through various media including participatory communication involving various parties so that there is an understanding of the perception of the importance of education without discrimination.

\subsection{Definition of Communication}

Communication planning is the first step for all types of activities. Including starting development activities, communication planning is a very important part. Sean MacBride negates that communication becomes a cultural tool that causes social integration. With communication, attitudes and motivations someone will be encouraged or influenced to behave, and it will extend to other environments. That is why, individuals with their awareness will play a major role in development (Kholil, 2019). According to Samsuddin (2019) Communication is a process where individuals in their relationships with other individuals, in groups, in organizations, and in society to provide information. Communication aims to tell or change the attitude, opinion, or behavior. In terms of the statement conveyer, communication that is informative and persuasive.

Shihabuddin Qalyubi (2007) stated that communication is a process of transferring or delivering news or news or information that contains meaning from one party to another in an effort to achieve mutual understanding. Based on the definition, it can be concluded that communication is an interaction in the form of delivering information involving two or more people with various types of information conveyed so that there is a common perception, relevance of information and responses about something communicated both in the form of statements, orders, prohibitions and others which essentially are a speech both orally and in writing.

\subsection{Participatory Communication}

Participatory communication is closely related to the communication model which contains five main concepts, namely (1) dialogue, (2) conscientization, (3) praxis, (4) transformation, and (5) critical consciousness (McPhail 2009). According to Tufte and Mefalopulos (2009), there are four basic principles that underlie the participatory 
communication process. There are 4 four principles in a participatory development program. The principles are: (1) dialogue, (2) voice, (3) liberating pedagogy and (4) actionreflection-action. If it is related to how to communicate as a form of "concientization" or "awareness" about inclusive education, an effective or participatory communication system is needed. Participatory refers to the involvement of various parties to unite the perception of the importance of providing education for all (Education For All). The shared perception is expected to motivate various parties who participate and work together to pay attention to the implementation of inclusive education.

\subsection{Definition of Inclusive Education}

The word inclusion comes from the English word "inclusion" which is used to describe the incorporation of children with disabilities into a school program. Inclusive Education is an educational organization that unites children with special needs and normal children in general to learn Smith and Thomas (Maher 2015).

Inclusive education is an effort to remove barriers to students and at the same time increase the opportunity to get education for all people, including children with special needs. Even so, the reality in the field to date, inclusive schools are still synonymous with mixing children with special needs with normal children. At present, our education still sees students with one lens, all children are the same, actually every child is born with their own differences and uniqueness. This means that every child must be given space or opportunity and the right to develop in accordance with the capacities and needs that they carry. (Asiyah, 2018).

\section{Research Methods}

This research method uses naturalistic research method because the research is conducted in natural condition (natural setting) in line with what Yin (2011) described. A research with qualitative method is a research method based on the philosophy of postpositivism, used to examine the conditions of natural objects (as opposed to is an experiment). The researcher is a key instrument, the data collection technique is carried out in a triangulation (combined) manner, the analysis is inductive/qualitative, and the results of qualitative research emphasize the meaning more than generalization.

This study produces descriptive data in the form of words from interviews and informants' behavior which are determined as sources of information related to the purpose of this study including the relationship of any information obtained from various aspects, as safely explained by Creswell (2012) that in qualitative research there is no apart from the relationship of the individuals studied in terms of culture, customs, language aspects and others that have certain characteristics.

\section{Results and Discussion}

\subsection{Implementation of inclusive education in Palu}

Realizing the implementation of inclusive education in Indonesia has been regulated through several laws as follows:

1) Law No. 4 of 1997 article 5 concerning children with disabilities;

2) Law No. 23 of 2002 articles 48 and 49 concerning child protection

3) Law No. 20 of 2003 article 5, paragraphs 1 to 4 concerning the National education system. 
4) Government Regulation of National Education No. 70 of 2009 concerning inclusive education

5) Governemtn Regulation No. 17 of 2010 articles 127 to 142, concerning the Management and Implementation of Education.

Responding to the above law, the Regional Government of Central Sulawesi, on December 16, 2014, declared itself an Inclusion Province marked by the signing of an MoU with the Mayor and Regent of Central Sulawesi. This declaration is an attitude of the local government in socializing the right to special education for students who have obstacles. The government's response to the implementation of special education, in this case including inclusive education, has been seen with the issuance of Governor Regulation Number 22 of 2020 concerning the management of the Madani Integrated State Special Education Unit whose orientation is specifically for Children with Special Intelligence/Special Talent.

The program for implementing inclusive education in Central Sulawesi Province has actually been implemented in districts/cities, this is evidenced by the existence of a decree on the appointment of several schools in Central Sulawesi province as schools that provide inclusive education number: 800.05 / 18.70 / PK-LK / DIKBUD on 11 February 2019 concerning schools that provide inclusive education. There are 119 schools that are officially designated as schools that provide inclusive education, while there are approximately 4188 education units in Central Sulawesi, both public and private (Data of Dapodik 2019/2020), meaning that there are only about $3.5 \%$ of schools that can accommodate/accommodate all children.

The cityof Palu has 277 schools and based on data from the Education and Culture Office of Central Sulawesi Province, only 36 schools have been officially designated as schools that provide inclusive education. This means that only $13 \%$ of schools provide inclusive education. This shows that the PUS system has not been running well, even though the Palu government strictly regulates the equal distribution of rights and obligations for every citizen to access education without discrimination. Education is carried out in a democratic and fair manner and is not discriminatory by upholding human rights. "This article emphasizes that education in Palu should be carried out without discrimination, but discrimination cases in the education sector in Palu still often occur, especially for children with special needs.

In this regard, the current government of Palu through the Education and Culture Office of Palu has made efforts by conducting socialization to education units, both school principals and educators through socialization about inclusive education at the elementary and junior high school levels by referring to schools the implementation of inclusive education which is currently one of the priority programs in serving students with special needs, as stated that inclusive education is a priority to serve students who have special needs to be able to learn like other normal children AS.Dikbud/KBJN [ M3.1].

A similar sentiment was also expressed by resource persons AA.POKJA/KBJN [M2.1] who said that the Education Office had not yet concentrated too much attention on the implementation of inclusion programs effectively. AA hopes that good communication will be built between the office and the school as well as the Working Group in bridging the process of inclusive education.

Likewise, the opinion expressed by the informant INS.PS/KOM[M2.1] said that from the observation so far, the implementation of inclusive schools, especially at the elementary school level, has been running but has not been maximized. This may be due to a lack of coordination and communication, so that in the future there needs to be improvements both internally and externally. So communication that has not been 
maximized can be maximized so that this program can run according to what we expect, especially in schools that have implemented inclusive education programs in formal education.

MB.LSM/SHOL Community Social Institution [M3.1] states that the government policy in fulfilling services for students with special needs in Palu, seen from the results of interviews with several informants related to inclusive education, has been socialized and some schools have even provided education. Inclusion is a form of manifestation of EFA but this implementation has not shown that inclusive education is a solution for most children with special needs and this is closely related to how communication between the government, in this case Palu Education and Culture Office as a determinant and policy maker, is the education unit itself and to the community, of course this is still a big job to implement the policy.

Several dilemmas as stated by Sunardi (2009) were also found in the implementation of inclusive education in Palu, especially in relation to the curriculum in schools that provide inclusive education has not accommodated the existence of children who have different abilities (disabilities) who are used in learning for students with special needs as the results of an interview with AS.Dikbud/KUR [M3.4] that the curriculum used by the host school is normal but how to approach these inclusive children however, if there is a special curriculum it means that children learn inclusively based on the curriculum and are automatically separated from other non-inclusion, because so far, in schools they get the existing curriculum, only the approach may be more specific, so that special skills are needed by an educator in handling it.

In line with this statement, FB.KS/KUR [M1.2] The principal of SMP Negeri 1 Palu as one of the schools implementing Inclusive Education since 2014 stated that at SMP Negeri 1 Palu, the curriculum used was the general 2013 curriculum. However, how do teachers see the differences in these children. When we know that a child has special needs such as autism, the coaching is more specific or more focused. Meanwhile, one of the teachers from SDN 15 Palu NJ.Gr/KUR[M1.2] stated that the inclusive education curriculum, seems to exist, but so far it is still integrated in the general curriculum of schools implementing inclusive education.

It is in line with what was stated by the SD Inpres 3 teacher Birobuli MR.Gr/KUR[M1.3], that there is no special curriculum yet. The school uses a general curriculum. However, for the report on learning outcomes (Rapport), the description explains the specific achievements in accordance with the specific needs provided by coaching. There is a special description column in the report card and it is possible that the standard value.

Regarding the problem of classroom learning for children with needs at schools that provide inclusive education, the Principal of SMA Negeri 4 Palu who is also the Chairperson of the Central Sulawesi PGRI SZ.KS/KUR [M1.3] stated that the principal and speakers were from the PKLK Education Office. revising or making efficient good efforts of certain subjects and materials to suit the mindset and circumstances of children with special needs, for example sports. When in that sport there is a volleyball game curriculum and children have physical obstacles, the learning is modified, so that the concept of volleyball is still understood even though they do not follow the practice of playing volleyball.

Based on the results of the interview, it can be ascertained that some of the curricula used by schools providing inclusive education have not accommodated the existence of special needs students, so it seems that the program of implementing inclusive education in Palu is only impressed by an experimental program. Likewise, the minimum or 
unavailability of Special Guidance Teachers (GPK) in providing services for Children with Special Needs according to their special needs.

The training action was carried out for teachers in Palu so that they have the ability to provide services for children with special needs carried out in the 2018 and 2019 fiscal years with 42 (forty two) teacher training participants. With the presence of educators who are trained to become Special Guidance Teachers, even this has not been able to accommodate students with special needs that exist and are spread across various levels of educational units in Palu.

Information about the existence of teachers, AS.Dikbud/KBJ/M1.1, M3.1] stated that inclusive education is a priority for the Palu Education Office in order to serve students with special needs so that students do not feel privileged but still learn like any other normal child. The Education Office will strive to prepare human resources through a process of training and education and training so that regions have human resources in their fields and place them in schools that have ABK. The Education Office will pursue policies that lead to special incentives for Special Guidance Teachers. Because, services for children with special needs extra skills and abilities both emotionally and pedagogically are needed in serving these children.

The same thing was conveyed by the Head of the Educator and Education Section Head of NL.Dikbud / GPK [M3.2] in relation to personnel in the service for Children with Special Needs, NL stated that the school prepared teachers who were believed to be able to handle Children with Special Needs who then included them in the training activities carried out by various parties. Meanwhile, SZ.KS/GPK [M1.1 / M3.1] stated that SMA Negeri 4 Palu has a GPK that has been trained through the Education and Culture Office of Central Sulawesi Province. GPK has the responsibility to socialize the existence and function of the school as a servant for children with special needs.

Also explained by NJ.Gr/GPK[M3.2] one of the GPKs said that attending training in the field of handling ABK is a form of attention from the Palu City Education Office to equip GPK with more skills than other teachers, so that it is expected to be able to handle ABK who is in its class. The ratio of teachers and the number of children with special needs in schools that provide inclusive education is still classified as inadequate, allowing it to have a significant impact on the success of implementing inclusive education in schools that provide inclusive education.

\subsection{Participatory Communication Model}

Participatory communication has elements such as freedom, equal rights and equal access. Every individual has the right to express their opinions, have their opinions heard, and provide equal opportunities for everyone to have their opinion without having to be pressured or combined with the voices of others. As in this research, the success of implementing inclusive education depends on the form of communication involving all relevant stakeholders, such as: parents, teachers, elements of local government, NGOs, and Mass Media.

As explained in the previous chapter, participatory communication is closely related to a communication model which contains five main concepts, namely (1) dialogue, (2) conscientization, (3) praxis, (4) change (transformation), and (5) critical consciousness (critical consciousness) (Mc. Phail, 2009). According to Tufte and Mefalopulos (2009), there are four basic principles that underlie the participatory communication process. The basic principles are: (1) dialogue, (2) voice, (3) liberating pedagogy and (4) actionreflection-action. The intensity of participatory communication between stakeholders related to the implementation of inclusive education in this study can be seen in the following: 
Table 1. Participatory Communication Intensity of Stakeholders with the Implementation of Inclusive Education

\begin{tabular}{|c|c|c|c|c|}
\hline \multirow[t]{2}{*}{ No } & \multirow{2}{*}{$\begin{array}{l}\text { Participatory } \\
\text { Communication } \\
\text { Intensity }\end{array}$} & \multirow[t]{2}{*}{ Category } & \multicolumn{2}{|c|}{$\begin{array}{c}\text { Informant } \\
\text { Number }\end{array}$} \\
\hline & & & People & $\%$ \\
\hline \multirow{3}{*}{1} & \multirow{3}{*}{ Dialogue } & Low & 4 & 20 \\
\hline & & Moderate & 3 & 15 \\
\hline & & High & 13 & 65 \\
\hline \multirow{3}{*}{2} & \multirow{3}{*}{ Voice } & Low & 2 & 10 \\
\hline & & Moderate & 4 & 20 \\
\hline & & High & 14 & 70 \\
\hline \multirow{3}{*}{3} & \multirow{3}{*}{$\begin{array}{l}\text { Liberating } \\
\text { Pedagogy }\end{array}$} & Low & 4 & 20 \\
\hline & & Moderate & 3 & 15 \\
\hline & & High & 13 & 65 \\
\hline \multirow{3}{*}{4} & \multirow{3}{*}{$\begin{array}{l}\text { Action- } \\
\text { reflection- } \\
\text { action }\end{array}$} & Low & 6 & 30 \\
\hline & & Moderate & 3 & 15 \\
\hline & & High & 11 & 15 \\
\hline
\end{tabular}

The results in table above show that $65 \%$ of informants in the research have high dialogue intensity. In the implementation of better inclusive education, especially in the service of children with special needs, it is necessary to prepare human resources through several training processes and education and training training, serving children with special needs requires skills and abilities both emotionally or pedagogically in serving children with special needs. Based on the excerpt from the interview results, it shows that the intensity of the voice created in this research is very high. Table 4 shows that $70 \%$ of informants have a high voice in participatory communication related to the implementation of inclusive education.

The excerpt from the interview results shows that voice is the center of dialogic communication based on awareness of the strength of human relationships. The excerpt from the interview results also shows that the voice or delivery of aspirations emphasizes the existence of space and time for the community, especially marginalized people to be considered. Therefore, stakeholders related to the implementation of inclusive education in Palu try to voice their opinions, translate their problems, design solutions for all of which related to inclusive education, to then do it together. These stakeholders voiced their opinion that the implementation of inclusive education is very important in accommodating the needs of children with special needs related to education in Palu.

As stated by (Firdaus, 2010) that education is an important part of the survival of a nation, and education for children has become an obligation to pay attention to. This is because children have a period that we call the golden age, where this period determines the next child's development. In relation to liberating pedagogy, Table 4.3 shows the existence of moderate and high intensity related to the implementation of inclusive education in Palu. Table 4.3 shows that the intensity of liberating pedagogy in the research was $20 \%$ low $15 \%$ moderate and $65 \%$ high. As stated by Muslikhah (2015) that in the process of liberating pedagogy or liberating learning, this is interpreted not only to help facilitate the channeling of aspirations or the process of disseminating information from those who don't know to know, but rather how to form a dialogue, so as to be able to identify problems. together and determine the solutions to be taken.

Some of the excerpts from the interview results are in accordance with those stated by Freire (2005). Liberating Pedagogy is a person's way of communicating through a dialogical process to help channel their aspirations (Freire, 2005). Furthermore, in several 
excerpts from the interview results, there are pillars of liberating pedagogy related to participatory communication concentrations related to the implementation of inclusive education, namely; (1) love; (2) humility (eliminating arrogance); (3) trust; and (4) hope. The results of this liberating pedagogy are called Freire (2005) as "scientilizacao", which can be translated as attaining "action-oriented" awareness or achieving action-oriented awareness.

The stakeholders involved in the participatory communication of the research indicated that there were proposals for efforts related to the implementation of inclusive education in Palu. Apart from voicing their aspirations, these stakeholders also propose various efforts based on the principles of inclusive education, namely:

1) All children can learn

2) All children attend regular, age-appropriate classes at their local school

3) All children receive an appropriate educational program

4) All children receive a curriculum that is relevant to their needs

5) All children participate in intracurricular and extracurricular activities

6) All children benefit from cooperation, collaboration at home, at school, among the community.

In line with action-reflection-action, Table 4 shows the existence of moderate and high intensity related to the implementation of inclusive education in Palu City. The intensity of the action-reflection-action in this study was 30\% low, 15\% medium and 55\% high. As the key word in action-reflection-action is to increase awareness and commitment to action in a group.

Based on this description, the communication model for the implementation of inclusive education in Palu is as follows: related stakeholders interact with each other for the success of implementing inclusive education in Palu. The management of the implementation of inclusive education in Palu is left to the local government and schools, parents, NGOs, and related Mass Media, they need to contribute/influence for its smooth running. Therefore, the formation of a communication concentration model for the implementation of inclusive education in Palu, in general, the implementation of inclusive education in Palu is successful if:

1) Unconditional acceptance of all children into regular class and school life.

2) Provide as much support as possible to children, teachers and classrooms as needed to ensure that all children can participate in their class.

3) Seeing all children at their potentials rather than what they cannot do (lacks).

4) Teachers and parents have high expectations for all children.

5) Developing educational goals according to the abilities of each child.

6) Designing schools and classrooms in a way that helps children learn and reach their full potential

7) Have a strong leadership to be included from school principals and other administrators.

8) Having teachers who have knowledge of different teaching methods so that children with different abilities and strengths can learn together.

9) Have principals, teachers, parents and others working together to determine the most effective way of providing quality education in an inclusive environment.

The implementation of the participatory communication system is illustrated in Figure 1 


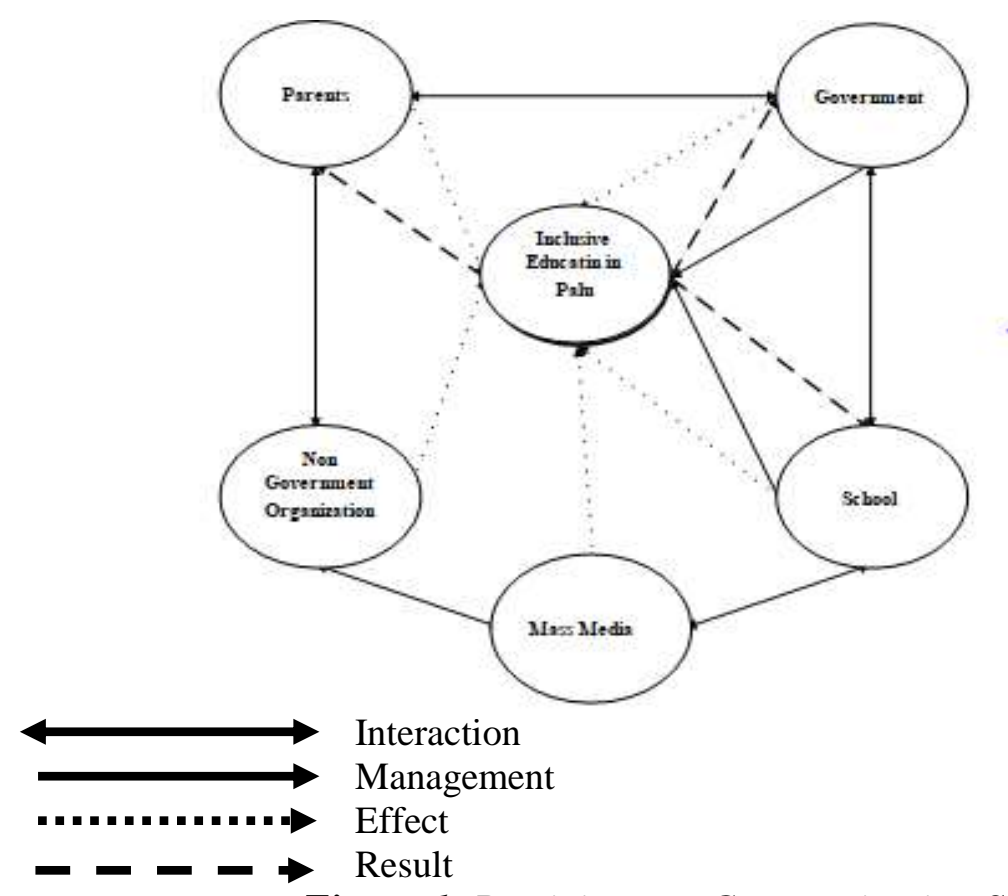

Figure 1. Participatory Communication System

\subsection{Embodiment of Participatory Communication Model of Inclusive Education}

The form of communication concientization in the implementation of inclusive education in Palu is based on the involvement and participation of stakeholders in inclusive education which refers to their real participation in educational activities. (see Figure 4, Quadrant 2 and Quadrant 4, Show Consideration (inform + consult); Work Together (inform + consult + collaborate)).

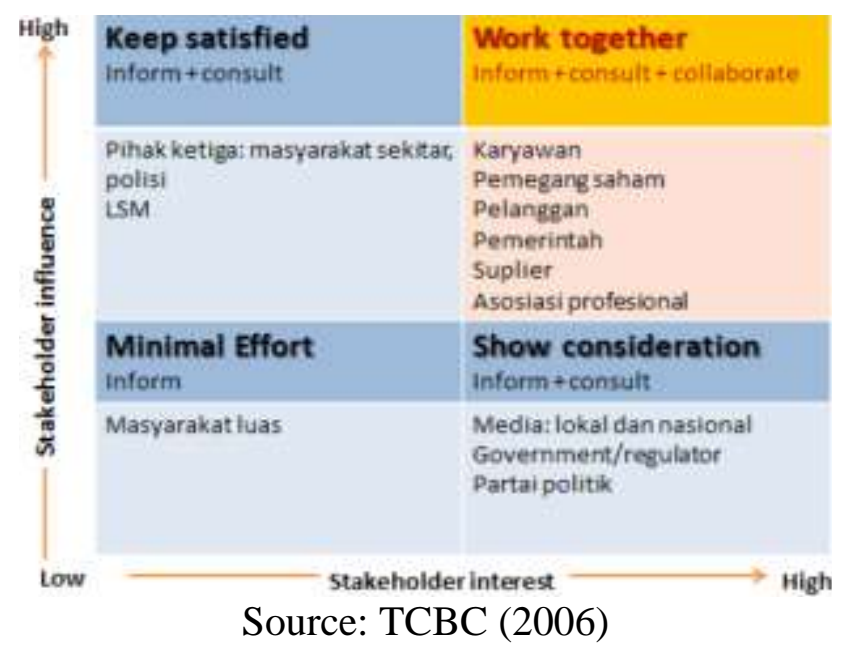

Figure 2. Stakeholders Engagement Model

Based on the stakeholder engagement model and the location of these quadrants, participation can be in the form of ideas, constructive criticism, support and implementation of inclusive education. Based on its scope, participation in inclusive education can be classified into three types, namely broad participation, narrow participation, and participation which is the opposite of political activity. Broadly speaking, participation in inclusive education can be interpreted as the democratization of education, in which stakeholders can determine goals, strategies and representation in the implementation of education policies. In a narrow sense, participation can be defined as the 
involvement of stakeholders in the entire process of change and community development in the field of inclusive education. As opposed to political activity, stakeholder participation can be interpreted as an effort to educate groups of people with different interests to propose rationally their various desires and voluntarily accept policies related to the implementation of inclusive education.

Good relations between schools that provide inclusive education with other stakeholders grow if they also feel the benefits and their participation in programs implemented in schools. Benefits can be interpreted broadly, because they include a sense of attention, respect and a sense of satisfaction because they can contribute to the interests of schools that provide inclusive education. So the principle of fostering relationships among relevant stakeholders can be done by giving mutual satisfaction to each other. One way is to establish good and effective communication concentrations.

The form of stakeholder participation related to the implementation of inclusive education can be developed in several aspects, including: First is managerial, stakeholders can be involved in various managerial processes that occur in schools that provide inclusive education by involving people who are considered to have management knowledge, so that in planning, implementing and evaluating, those involved can contribute to developing and advancing the school. Second is financial, an assumption that develops in the school environment in general and most of the community considers that the current cost of education is a burden on parents, especially for private schools that have more facilities, to get maximum service for children with special needs. According to the author, this is a sign that this assumption is trapped in a lack of understanding and incomprehension in mobilizing participation or establishing interactions between schools and stakeholders related to fulfilling facilities for children with special needs. It is time for students not to be burdened with education costs. The school is fully responsible for this, namely by establishing participation with relevant stakeholders (parents, entrepreneurs, government, other educational institutions, NGOs, mass media, and other related parties) to address this. The free education that has been proclaimed by the Palu government has not accommodated the needs of schools that provide inclusive education. Thirs is materials, especially in the development of learning facilities, increasing awareness and concern for the implementation of inclusive education by developing the supporting facilities and infrastructure needed in relation to the implementation of education. Fourth is academically, in terms of curriculum preparation, it can involve stakeholders who have educational scientific backgrounds and are experts in the field of curriculum related to inclusive education. Fifth is cultural, it cannot be denied that schools that provide inclusive education are held in a community environment that must be able to represent the various needs of the community related to this education. The sixth is mediative, namely involving the community as a trainer or resource person for learning and training for both educators and students if needed. As is the gap in this research that so far the weakness of the participatory communication model is that it has never considered the mass media as one of the elements forming the model. Therefore, in relation to the implementation of inclusive education in Palu, the mass media as one of the relevant stakeholders is considered to have an important role in the progress of inclusive education. Mass media plays an important role in today's life, not only as a place for information and a place to convey opinions, but also as a place for mass media to play an important role in education, especially inclusive education. 


\section{Conclusion}

1. The stakeholders involved in the participatory communication of this study indicated that there were proposals for efforts related to the implementation of inclusive education in Palu. Apart from voicing their aspirations, these Stakeholdres also proposed various efforts based on the principles of inclusive education, namely that: a) All children can learn; b) All children attend regular, age-appropriate classes at their local school; c) All children receive an appropriate educational program; d) All children receive a curriculum that is relevant to their needs; e) All children participate in extracurricular and extracurricular activities; f) All children benefit from cooperation, collaboration between home, at school, among the communities.

2. The communication model for the implementation of inclusive education in Palu y must involve various stakeholders consisting of local governments, schools, parents, NGOs, and local mass media. Thus, based on this description, the communication model for the implementation of inclusive education in Palu must involve relevant stakeholders who interact with each other for the success of implementing inclusive education in Palu. The management of the implementation of inclusive education in Palu is left to the local government and schools. Although management is left to the local government and schools, parents, NGOs, and related mass media also need to contribute/influence for the smooth running of inclusive education in Palu.

3. The realization of the participatory communication model in the implementation of inclusive education in Palu is based on the involvement and participation of stakeholders in inclusive education which refers to their real participation in educational activities. The involvement of stakeholders in the communication model for implementing inclusive education in Palu City is as follows: a) Parents of students, as the people closest to students so that they are able to provide a real picture of the behavior, development, characteristics, and abilities of students; b) Class teacher; supervisor of all students in his class, including children who have obstacles during class classically; c) Special guidance teacher; the main supervisor of students with special needs while in school; d) Principal; who validate, provide input, and supervise the learning process e) Local government; providers of inclusive education policies f) NGOs as stakeholders provide information and explanations about the implementation of education for special needs students to various interested parties; g) Mass media; Information media for the implementation of inclusive education play an active role in informing the community about ABK services.

\section{References}

Allen, E \& Cowdery, G. (2012). The exceptional Child: Inclusion in Early Childhood Education, Seventh Edition. United States of Amarica: Wadsworth Cengage Learning.

Asiyah, D. (2018). Dampak Pola Pembelajaran Sekolah Inklusi terhadap ABK. Prophetic, $1(01), 69-82$.

Creswell, John W. (2012). Research Design Pendekatan Kualitatif, kuantitatif, dan Mixed. Yogjakarta: Pustaka Pelajar

Firdaus, E. (2010). Pendidikan Inklusif dan Implementasinya di Indonesia, 2.

Freire, P. (2005). Pedagogy of The Oppressed. 30th anniversary edition. New York: Continuum 
Indaki, N. 2007. Communicating The Impact ofCommunication for Development. Recent Trends in Empirical Research. World Bank Working Paper

Liliweri, A. 2011. "Komunikasi Antar Personal" Jakarta: Remaja Rosdakarya.

Kesadaran. (2019). Re-Konsientisasi dalam Dunia Pendidikan. 8 (1), 1-12. 41-44.

Kholil, S. (2019). Communication Planning of Langsa City Government in Building an Islamic and Environmentally Friendly City. Budapest International Research and Critics Institute-Journal (BIRCI-Journal). P. 638-644

McPhail , T. L. 2009. Development Communication: reframing the role of the media. 1st edition. West Sussex, United Kingdom: Blackwell Publishing Ltd

Miles, M.B and Huberman A.M. 1992. Analisis Data Kualitatif Buku Sumber Tentang Metode-Metode Baru. Jakarta: UIP

Moleong, L.J. 2000. "Metodology Penelitian Kualitatif", Bandung: PT Remaja Posdayakarya.

Muslikhah, FP (2015) "Komunikasi Partisipatif Pada Kelompok Wanita di Kecamatan Kajoran Kabupaten Magelang". (Tesis) Bogor (ID):IPB

Muhadjir, N. 1996. "Metodologi Penelitian Kualitatif". Yogjakarta: Rake Sarasin

Muh. Idris. (2009). Pendidikan Pembebasan (Telaah Terhadap Pemikiran Paulo Freire). Jurnal Dinamika Ilmu, 9(2), 2.

Rohinah.R. 2019 "Rekonsientisasi dalam Dunia Pendidikan (Membangun Kesadaran Kritis melalui Pemikiran Paulo Freire" Jurnal Ilmiah Kependidikan Vol.8 hal. 1-12.

Samsuddin, and Ananda, R. (2019). Communication of School Heads in Improving Education Performancein SMA Plus Private Vocationa School, Al-Azhar Medan. Britain International of Linguistics, Arts and Education Sciences (BIoLAE) Journal, 8- 15.

Sendjaja, S. D. P. . (2014). Komunikasi: Signifikansi, Konsep, dan Sejarah. Pengantar Ilmu Komunikasi, XII, No. 1(3), 1-41.

Sudarto, Z. (2017). Implementasi Kebijakan Penyelenggaraan Pendidikan Inklusif. Jurnal Pendidikan (Teori Dan Praktik), 1(1), 97.

Syaikhudin, A. (2012). Konsep Pemikiran Pendidikan Menurut Paulo Freire Dan Ki Hajar Dewantoro. Cendekia: Jurnal Kependidikan Dan Kemasyarakatan, 10(1), 79.

Servaes, J. 1996. Linking Theoretical Perspectives to Policy. in J. Servaes,T. Lacobson, $\&$ S. A. White (Eds.), Participatory Communication For Social Change (Pp. 29-43). New Delhi, India: Sage Publication India.

Servaes, J. and Malikhao, D. 2007. Communication and Sustainable Development, Mapping The Paths Between Communications, Technology, and Social Change in Communities. UK: Southbound.

Sunardi. 2009. Issues and Problems on Implementation of Inclusive Education for Disable Children in Indonesia. Tsukuba: CRICED - University of Tsukuba.

Torfaen County Borough Council (TCBC). 2006. Stakeholder Engagement-A Toolkit. REVIT Project.

Tufte, T., and Mefalopulos, P. 2009. Participatory Communication: A Practicalguide. Washington, DC: World Bank.

Van de Fliert, E. 2010. Participatory Communication in Rural Development: What Does it Take for The Established Order? Extension FarmingSystems Journal, 6(1), 96-100.

Yin, R. K. (2011). Qualitative Research from Start to Finish. New York: Guilford. 